\title{
High Risk Mantle Cell Lymphoma International Prognostic Index Combined Biologic Index
}

National Cancer Institute

\section{Source}

National Cancer Institute. High Risk Mantle Cell Lymphoma International Prognostic

Index Combined Biologic Index. NCI Thesaurus. Code C137810.

High risk MIPI score (6-11) and Ki-67 greater than or equal to 30\%. A MIPI-c high risk equals a MIPI-c score of 3. 